\title{
Wading in Troubled Waters: Supporting the Work of the International Criminal Court (ICC) through Domestic Legal Institutions in Kenya
}

Laurence Juma*

DOI: $10.21827 / 5 \mathrm{~d} 5141 \mathrm{c} 1 \mathrm{~b} 8577$

\section{Keywords}

ROME STATUTE OF THE INTERNATIONAL CRIMINAL COURT;

INTERNATIONAL CRIMES ACT (2009); POST-ELECTION VIOLENCE 2008; COMPLEMENTARITY

\begin{abstract}
This article discusses the role of Kenyan domestic legal institutions in supporting principles and institutions of international criminal justice. It discusses how these legal institutions have interacted, supported and even applied the principles of international criminal justice amidst a very hostile political climate. This article argues that the current calls for withdrawal from the Rome Statute of the International Criminal Court may be frustrated by these institutions because they have greater affinity to the principles of international criminal justice than political establishments. While acknowledging that the eradication of impunity should be a joint effort between domestic and international institutions and that the current tensions and calls for withdrawal are not good for everyone, the article argues that neither international institutions alone nor domestic systems can make progress unless there is collaboration as well as reforms in the entire international criminal justice system.
\end{abstract}

\section{Introduction}

This article explores an interesting phenomenon in Africa's relationship with the International Criminal Court (ICC), which is the apparent discord between the external policy agenda as espoused by political leaders, and the seemingly grounded support for the ICC and the international criminal processes by internal legal institutions in most African states. Whereas in their collective, African leaders have condemned the ICC and are actively seeking ways of curtailing its authority to deal with powerful political figures across the continent, their desire to disengage completely from the ICC will probably be difficult to attain. Some of the factors which make such an intent difficult to fulfil, resonate with just about everything that is problematic with Africa's relationship with the international system. For example, their dependency on the developed north eliminates the possibility of the continent charting an independent path in dealing with impunity. The other is the apparent inability of African states in their collective to influence "governance' beyond the continent, ${ }^{1}$ a factor largely contingent on the paucity of resources

LLB (Nairobi); LLM (Pennsylvania); MA (Notre Dame); LLD (UFH), Professor of Law, Rhodes

University, South Africa. I wish to acknowledge the research assistance by Phoebe Oyugi.

Martin Welz, 'The African Union beyond Africa: Explaining the Limited impact of Africa's

Continental Organisation on Global Governance' (2013) 19 Global Governance 425. 
and their propensity to seek short term fixes to their problems. Then there is diversity and the impracticability of all 53 states in the continent speaking with one voice on any issue. ${ }^{2}$

Apart from the foregoing, one other factor that has become important lately and which invites further discussion, purposely because it steers the debate way from the emotive discourses around Africa's role in the international system, is the clear manifestation of the accommodation of the principles of international criminal justice and even support of the ICC by domestic legal institutions. Although focusing on domestic institutions may appear illusive considering that African political elite have in the past been able to manipulate these institutions to secure their own positions, a trend is emerging, especially in countries where new constitutions have been enacted such as South Africa and Kenya, where international law is considerably strengthened and the influence of its institutions widely acknowledged. ${ }^{3}$ Domestic legal institutions in these countries that are modelled out of the new constitutional dispensations have imbibed international standards in a variety of ways that make elite manipulation more visible and somewhat problematic. So, as differences arise between the political elite and international bodies, such as the current haranguing around the role of ICC in Africa, domestic institutions that foster international standards have proven capable of mediating the differences and upholding the promise of international law.

It is in this context that the role of Kenya's domestic legal institutions in fostering the principles of international criminal justice is discussed. The purpose is twofold: to show how the domestic legal institutions have interacted, supported and even applied the principles of international criminal justice amidst a very hostile political climate, and to illustrate why the current calls for withdrawal from the Rome Statute may be frustrated by the domestic legal system that has a greater affinity to the principles of international criminal justice than political establishments. This article has three parts. The first attempts to broadly identify the points of divergence in the on-going tense relationship between African states and the ICC. This part begins with a narrative on Africa's involvement in the establishment of the court and then posits a few critical thoughts on why the relationship stagnated and then became hostile. The second part analyses the attempts that

Theresa Reinold, 'Constitutionalization? Whose Constitutionalization? Africa's ambivalent Engagement with the International Criminal Court' (2012) 10 (4) ICON 1076, 1090. Mireille Affa'aMindzie, 'African Leaders Speak with one Voice, But on whose Behalf?' (Global Observatory, 26 February 2014http://theglobalobservatory.org/analysis/686-african-leaders-speak-with-one-voice-buton-whose-behalf.html) <http://theglobalobservatory.org/analysis/686-african-leaders-speak-with-onevoice-but-on-whose-behalf.htm; > accessed 12 October 2016.

The South African post-apartheid Constitution adopted in 1996 has provisions which allow domestic courts to apply international law such as sections 231,232 , and 232. This is holding that the Constitution should be interpreted "to comply with international law". Glenister v President of the Republic of South Africa 2011 (3) SA 347 (CC), Para 97. Mlambo asserts that: "The Rome Statute gives effect to international human rights law and enables the prosecution of customary international law crimes. As such, its provisions enjoy pre-eminence in our constitutional regime. Moreover, it has been domestically enacted. Its binding status is clear"). National Commissioner of The South African Police Service v Southern African Human Rights Litigation Centre and Another (CCT 02/14) [2014] ZACC 30. Article 2 of the Kenyan Constitution adopted in 2010 is much more explicit in this regard. J Osogo Ambani, 'Navigating past the 'dualist doctrine': The case for progressive jurisprudence on the application of international human rights norms in Kenya' in Magnus Killander ed, International Law and Domestic Human Rights Litigation in Africa, (Pretoria University Press, 2010) 25. Oppong argues that trends seem to be changing in favour of application of international law in domestic courts in Africa). Richard Oppong, 'Re-imaging International Law: An examination of recent trends in the reception of international law into national legal systems in Africa' (2006) 30 FordhamIntlLJ 296. 
have been made to withdraw from the Rome Statute, both continentally and in Kenya, and suggests why these attempts have been mostly unsuccessful. The third part identifies aspects of the Kenyan legal system that have shown support to the principles of international justice. Based on the assumption that the future of international criminal justice and the continued viability of its institutions rests on the support of domestic institutions, this article identifies trends and developments in the Kenyan legal system that carry such a promise. The idea is to demonstrate that these developments, as well as the modes of operations of these legal institutions are making it difficult for political leaders to align their anti-ICC rhetoric with national standards and aspirations. ${ }^{4}$ Finally, the article suggests that making assumptions about Africa's relationship with the ICC based solely on the rhetoric of political leaders and the tantrums of the African Union (AU) may be less useful than eliciting insights on how modern institutions that function within the constraints of political power may become key to ending impunity in the continent.

\section{Disengaging from the ICC: Legal and Political Imperatives}

Although Africa was the greatest supporter of the ICC before and immediately after it was created, it is now its greatest critic. This has prompted questions as to what has changed in the interim. One commentator has suggested that the reason for this change is rooted in Africa's ambivalence to international normativity, often reflected in its inability to translate global standards of governance into actual domestic practice. ${ }^{5}$ This means that Africa's disenchantment with the ICC must be viewed in the wider context of the shift from politics to law in the international system, ${ }^{6}$ or what Romano has characterised as the shift from the "consensual paradigm" to the "compulsory paradigm". ${ }^{7}$ On the other hand, Africa's change of heart could be a reflection of its reawakening and therefore, assertiveness in addressing the weaknesses in the international system. Although doubtful, this view seems to rekindle the old memories of the early 1960s when a vibrant Africa entering the UN, shaped the course of politics and came away with several reforms in international governance. Currently, Africa's influence is minimal and there is only a handful of issues on which its voice is heard. As far as peace and security is concerned, one issue that the international community and the UN will have to take seriously, is the reform of some of its organs, especially the Security Council. As Akande et al note,

Today, from the perspective of many African leaders, the ICC's involvement in Sudan has come to reflect their central concern about the UN-the skewed nature of power distribution within the UNSC and global politics. Because of the UNSC's legitimacy deficit, many African and other developing countries see its work as 'a cynical exercise of authority by great powers', in particular, the five permanent members. The

An example is the Omar Al-Bashir case in South Africa where arrest of warrant was issued for Omar Al-Bashir and the government disregarded the court order. Southern Africa Litigation Centre v Minister of Justice and Constitutional Development and Others (27740/2015) [2015] ZAGPPHC 402. (24 June 2015) (where a warrant of arrest was issued for Omar Al-Bashir and the government disregarded the court order). See also Sarah Evans S, 'Govt Denied Leave to Appeal Al-Bashir Case' (Mail \& Guardian, 16 September 2015 <http://mg.co.za/article/2015-09-16-govt-denied-leave-to-appeal-al-bahir-case>) $<$ http://mg.co.za/article/2015-09-16-govt-denied-leave-to-appeal-al-bahir-case > accessed 20 October 2016.

Reinold (n 2) 1090.

Laurence Juma, 'Unclogging the Wheels: How the Shift from Politics to Law Affects Africa's Relationship with the International System' (2014) 23 (2) Journal of Transnational Law \& Contemporary Problems 101.

Cesare Romano, 'The proliferation of international judicial bodies: The pieces of the puzzle' (1999) NYUJIntlL\&Pol 713. 
UNSC's (dis)engagement with article 16 since the Rome Statute became operative will have exacerbated rather than softened those impressions. ${ }^{8}$

Other scholars suggest that the current hostility to the ICC should be viewed in a political context. ${ }^{9}$ They argue that the inability of states to enforce obligations arising from a treaty to which they are a party, correlates to the political risk that exists in countries that do not observe the rule of law, have weak systems of governance and poor record for human rights. In these countries, compliance with informal enforcement mechanisms, such as those of international tribunals, is at risk when political circumstances change or when such mechanisms threaten political establishments. That is why the ICC's involvement becomes involves a political risk that even jeopardizes the commitment to the Rome Statute. Connected to this view, is the fact in these countries, ratification of treaties bears no cost. ${ }^{10}$ This in-turn invites non-compliance with informal rules and international treaties. Kenya is good example in this regard. The gradual breakdown of the rule of law and run-away corruption have made any attempts to enforce international criminal justice unpopular with the ruling elite. The change in attitude towards the ICC is therefore consistent with the political risk mentioned above.

Undoubtedly, these views play out rather critically in the review of Africa's relationship with the international system and may indeed influence the manner in which the international community responds to the tension between African Union and the ICC. It should be noted that mapping the interactions between the international criminal justice system and African states, and proffering solutions to the problems abiding in that relationship requires a much more sophisticated enquiry than has been provided by current political posturing and empty rhetoric of African leaders. One thing to note is that the interplay between politics and law in this regard, is a factor lawyers should not be shy to address, especially now that the tension is threatening the future of the Court. It should be recalled that the ICC was established outside the UN Security Council framework, to promote international rule of law by institutionalising checks on abuse of power and holding leaders accountable for international crimes without the undue interference of politics. It had nothing to do with political compromises or readjustment of geopolitical power. Unlike its predecessors, the International Criminal Court for Yugoslavia (ICTY), and International Criminal Court for Rwanda (ICTR), ${ }^{11}$ the ICC is a permanent edifice that is not vulnerable to the so-called victors' justice. The court was designed with a noble universal purpose. Africa's participation in its establishment thus signified a watershed moment in the fight against impunity, given that the aberrations that prompted the establishment of the Court had a greater endurance in Africa. It was a strong statement of support for the rule of law. Given this history, what is happening now is somewhat of an anti-climax to the progressive aspirations of the past. Thus, the efforts to withdraw from the Rome Statute and disengage from international criminal justice processes that do not respect immunity of heads of state, whether motivated by the ambivalence of African

Dapo Akande, Max Du Plessis and Charles Jalloh, An African Expert Study on African Union Concern About Article 16 of the Rome Statute of the ICC (2010), 6.

Susanne D. Mueller, 'Kenya and the International Criminal Court (ICC); Politics of Election and the Law' (2014) 8(1) Journal of East African Studies 25. Beth Ann Simmons and Allison Dammer 'Credible Commitment and the International Criminal Court' (2010) 64 (2) International Organization 225.

Oona A. Hathaway, 'The Cost of Commitment' (John M. Olin Center for Studies in Law, Economics, and Public Policy Working Papers, 21 May 2003) <http://digitalcommons.law.yale.edu/lepp_papers/273/> accessed on 12 October 2016.

UNSC Res 955 (8 November 1994) UN Doc S/RES/955. 
states to global standards of governance or the genuine need for reform of international institutions, may eventually undermine the progress the international community has made thus far towards eradicating impunity and promoting the rule of law.

Notable efforts to disengage from the ICC have occurred at two levels-the continental level and the national level. Movements at both levels only began after the ICC moved against heads of state. And the two situations that standout in this regard are Sudan and Kenya. There is a wealth of literature on the genesis of the tension between Africa and the ICC arising from the two situations, and it may not be useful to repeat them here. ${ }^{12}$ However, it may be worthwhile to mention that the indictment of the Sudanese President Omar Al Bashir in 2005 on charges of war crimes, crimes against humanity and genocide and the subsequent issuance of the warrant of arrest against him, marked the beginning of the contests between the African political leaders and the ICC. ${ }^{13}$ Subsequent commencement of proprio motu investigation against Kenya's President, Uhuru Kenyatta, and Deputy President, William Ruto, and four other high ranking government officials, simply added fuel to the fire. ${ }^{14}$ Although the Kenyan cases have now been terminated, African states still view the court as an imperialist tool used by western nations to bully developing states. The court is thus accused of ignoring the international law principle of immunity, and thus of failing to interpret its mandate in accordance with international law. A lot has happened since 2005 but what is pertinently clear is that African states and the African Union have been so outraged by these two situations, that they have made, and are still making efforts to disengage from the ICC.

\section{Attempts to disengage from the ICC}

The Kenyan situation is a bit intriguing. While Kenyan leaders have been very active at the AU level, internal developments depict a mixed response. There have been two attempts by the Kenyan parliament nudging the executive towards the process of withdrawal from the ICC. In both cases, the parliament passed motions supporting such withdrawal, but with little follow up being made to give effect to the wish of the legislature. The first attempt was in December 2010 followed by another attempt in September 2013. A few observations may be pertinent before an analysis of the actual episodes of attempted withdrawals. The first is that the ICC factor has always been used to square internal political problems. It is not about whether the ICC is good or bad for the purposes for which it was established, but how it can be used to secure political gains. That is why today, the politicians may want the ICC and tomorrow, they might want to reject it. As they oscillate between the two poles they carry government institutions with them and mess them up in the process. Second, the attempts to withdraw from the ICC have never enjoyed unanimous support. During the previous coalition regime, the factions led by Raila Odinga were bitterly opposed to any attempt to remove Kenya from the ICC. The same situation obtains today with the opposition members in parliament walking out during the withdrawal debate. Therefore, it cannot be said that Kenyans have at any one point unanimously supported the current efforts by the Uhuru government to remove the

For example, Gwen P. Barnes, 'The International Criminal Court's ineffective enforcement mechanisms: The indictment of President Omar Al Bashir' (2011) 34 (6) Fordham IntlLJ 1589. Christine Bjork and Juanita Goebertus, Complementarity in action: the role of civil society and the ICC in rule of law strengthening in Kenya, " (2011) 23 Yale HumRts \& Dev L J 383. referred the Darfur situation to the ICC. UNSC Res 1325 (31 March 2005) UN Doc S/RES/1593. Max Du Plessis, 'Kenya Again Tests Africa's Commitment to the ICC' Institute of Security Studies (2011). 
country from the Rome statute. Here again we see how the external policy is not quite in harmony with the domestic realities.

\section{II.I Background}

A little background may be useful to shed some light on the circumstances in which these attempts have been made, and why little success has been forthcoming. Kenya signed the Rome Statute of the International Criminal Court in 1999 and ratified it in 2005. At the time, there was little political risk because it seemed highly unlikely that any Kenyan would be tried by the court. ${ }^{15}$ Moreover, the country was enjoying considerable peace as compared to most of its neighbours. Things changed after the post-election violence of 2007. Efforts to return things to normal, saw the establishment of a commission of enquiry to investigate the violence and make recommendations for future action. This Commission, known as the Waki Commission, recommended that a credible local regime for investigation and prosecution of those responsible for the instigating and committing egregious crimes, should be established. It also suggested that if such a tribunal was not established, then the matter ought to be referred to the ICC because the offences committed meet the threshold for international crimes falling within the jurisdiction of the The Hague court. ${ }^{16}$ Such an option, the Commission suggested, would then be supported by a list of names of persons worthy of investigation, which it handed to Kofi Annan for onward transmission to the OTP, should that become neccessary. The recommendation to set up a special tribunal to deal with international crimes was deemed appropriate at the time because Kenya had not enacted a legislation to implement the Rome Statute, neither did the Penal Code, its primary criminal legislation, provide for such offences. ${ }^{17}$ After the Waki Report was published, the government committed itself to the establishment of the tribunal. The Bill for the Special Tribunal was hurriedly drafted by the Attorney General and placed before parliament. In a bizarre bout of intemperate miscalculation, parliamentarians rejected the Bill despite the impassionate plea by President Mwai Kibaki and Prime Minister Raila Odinga. ${ }^{18}$ A majority of Kenya's prominent politicians, outside the inner cohort of Odinga's ODM party, supported the idea of referring the cases to the ICC in apparent defiance to what they perceived as the PM's political agenda. ${ }^{19}$ They proceeded to appropriate the short lived moral triumph over Odinga with relish, branding the PM's proposal as vague and malicious. ${ }^{20}$ Having failed to establish a local tribunal, pressure began to build on Kofi Annan to approach the ICC and hand in the list of names suggested by the Commission for investigations, and he did so. There was also pressure on the government to fulfil the commitments it made in the accord. Having failed to secure parliamentary support for the establishment of the tribunal,

Mueller (n 9) 26.

Government of Kenya, Report of the Commission of Enquiry into Post Election Violence (CIPEV 2008) 472.

Antonita Okuta, 'National Legislation for Prosecution of International Crimes in Kenya' (2009) 7 JICJ 1065.

Thomas Hansen, 'Transitional Justice in Kenya: An Assessment of the Accountability Process in Light of Domestic Politics and Security Concerns' (2011-2012) 42(1) Case Western International Law Journal 8. Stephen Brown and Chandra Sriram, 'The Big Fish Won't Fry Themselves: Criminal Accountability for Post-Election Violence in Kenya' (2012) 111 (443) Afr. Affairs 244.

The same politicians had also frustrated the efforts to establish a functional truth and reconciliation process. See Godfrey Musila, 'Options for transitional justice in Kenya: Autonomy and the challenge of external prescriptions' (2009) 3 International Journal of Transitional Justice 449. 
the government hastily set up the Truth Justice and Reconciliation Commission (TJRC) to deal with crimes committed during the post-election violence. ${ }^{21}$

In March 2010, Pre-trial Chamber II of the ICC authorised the prosecutor to begin investigation of the violence in Kenya with a view to bring charges against individuals most responsible for the crimes that were committed. ${ }^{22}$ The prosecutor immediately announced that six Kenyans were under investigation. These included Uhuru Kenyatta and William Ruto. The six, except Sang, the radio journalist, were prominent government personalities - three cabinet ministers, one former minister, the secretary to the cabinet, and the former police commissioner. When the prosecutor, Louis Moreno Ocampo announced his decision to bring charges, Kenya's political class was rattled because unlike what they are used to, the international criminal justice process was beyond their control. However, because they had scuttled the process for establishment of a local tribunal, their immediate resolve was to assert Kenya's sovereignty and attempt to defeat the international legal process by political means. Politicians allied to those facing charges at the ICC, began to mobilise support for Kenya's withdrawal from the ICC altogether. ${ }^{23}$ And this is how the legislature became involved in the process.

\section{II.II The First Motion of Withdrawal}

In December 2010, a motion for parliament to support the withdrawal of Kenya from the ICC was tabled by Isaac Ruto, a key ally of William Ruto, one of the suspects indicted by the ICC. ${ }^{24}$ Prior to this there had been an intense campaign by politicians to depict the court as an instrument of imperialism. During the debate in parliament this view was unashamedly harped on by many speakers. One government Minister, who supported the motion, was quoted saying that the court was only for Africans and that "no American or British will be tried there". ${ }^{25}$ The MPs voted in support of the motion thus paving the way for the government to begin cutting its ties with the ICC. The motion was seen as an affront to the government which many of them saw as being uncooperative in protecting Kenyan leaders. There were those who legitimised their call for withdrawal on the somewhat unfounded allegation that the Prime Minister was using the ICC to eliminate his political rivals. The politicians had conveniently forgotten that it was the Prime Minister that had urged them a few months back to establish a local tribunal. This attests to the dishonesty of Kenyan politicians in the whole ICC debate.

Although the motion was passed, supposedly paving the way for the government to adjust its relationship with the ICC, nothing took place. The coalition government was perhaps too tenuous to attempt something as drastic as adjusting its international relations with a powerful organ as the ICC. Moreover, given the embarrassment that it had suffered when it allowed Bashir into the country the risk might have been too great. Another factor could have been that the motion came at the twilight of the coalition government's tenure.

Mba Nmaju, 'Violence in Kenya: Any role for the ICC in the quest for accountability' (2009) 3 African Journal of Legal Studies 90. The Truth, Justice and Reconciliation Commission Act 2008 was passed in October 2008.

Charles Jalloh, 'Situation in the Republic of Kenya, No ICC-01/09-19 Decision on Authorisation of Investigation' (2011) 105 AJIL 540.

Hansen (n 18) 10.

Eunice Rugene, 'Kenya Lawmakers vote to pull out of international criminal court' (Monitor UK, 24

December $2014<$ http://www.monitor.co.ug/News/World/-/688340/1078072/-/10hdnbv/-

/index.html > accessed 20 October 2016.

'Kenya MPs vote to leave ICC over poll violence claims' (BBC News, 23 December 2010

$<$ http://www.bbc.com/news/world-africa-12066667> accessed 20 October 2016. 
With elections looming, none of the key players could have been brave enough to devote their time towards sorting out matters with foreign policy implications, when there was already plenty of national issues deal with. But although the Kibaki/Raila coalition government did not take any action to withdraw from the treaty it wasn't entirely certain that it supported the ICC process. In fact, judging from some of its action, the government appeared to be a bit uncomfortable with the ICC process and was leaning more towards protecting the accused persons, than discharging its obligations under the Rome Statute. For example, the government despatched the then Vice president, Kalonzo Musyoka, on a diplomatic tour of African countries to seek support of its application for deferral of the cases under article 16 of the Rome Statute. ${ }^{26}$ The request, which was formally lodged in February 2011, alleged that the deferral would foster peace and reconciliation. The request was not formally considered by the Security Council due to the differences amongst the parties in the coalition.

In the meantime, the ICC process proceeded. In March 2011, the ICC summoned the accused persons to appear before it for a confirmation of charges hearing. At this point the Kenyan government, perhaps energized by the motion of withdrawal, decided to seek dismissal of the charges against the accused on the grounds of admissibility. It became clear that the government was not interested in pursuing withdrawal from the ICC but rather pursuing the termination of the trial through procedures established by the Rome Statute. Perhaps this was upon realisation that any steps taken to withdraw from the treaty may not affect the on-going trials. The application was dismissed thus paving the way for the trial to proceed. ${ }^{27}$ One can therefore conclude that the first motion of withdrawal was a wasted effort. It had no effect internally other than to whip political emotions, and externally too, on the ICC process, which was, after all, its intended target.

\section{II.III The Second Motion of Withdrawal}

The political onslaught on the ICC took a different turn as the Kibaki/Raila coalition government's term drew to an end. Much of the venom was now directed at Raila Odinga who was then a leading contender for the presidency. Indeed, the bitterness towards the ICC and Odinga fermented the relationship between Uhuru Kenyatta and William Ruto who were both presidential contenders as well. The two were able to form a coalition between their two political parties, URP and TNA, and contest for the positions of president and vice president respectively. In a highly charged campaign, the duo presented themselves as fighting for the sovereignty of country against external interference. When they won the election and assumed office, the onslaught against the ICC was energised as all government efforts were now solely directed at dealing with it and ensuring that the President and his vice president were absolved. Although they both pledged to cooperate with the ICC and "clear their names", which appeared as something of an anachronism, much of what they did in their administration was directed at frustrating the ICC trial. No wonder soon after their inauguration, the political discourse once again revived the move towards withdrawal of the country from the ICC. Against the backdrop of an all-out war against the ICC by government, another motion for withdrawal was tabled in parliament

Walter Menya, 'Fresh Shuttle diplomacy on ICC Cases' (The Star, 1 May 2012) <http://www.thestar.co.ke/news/article-20219/fresh-shuttle-diplomacy-icc-cases> accessed 26 November 2016. This move was highly criticized by the Law Society of Kenya and other civil society groups as being wasteful. The Kenya national Commission of Human Rights lamented the use of public resources to protect "criminals". 
on 5 September 2013. According to Adan Duale, the Majority Leader in Parliament, who proposed the motion, there had been a "fundamental change in circumstances relating to governance" since Uhuru and Ruto had been "lawfully' elected to lead the country. ${ }^{28}$ Parliament was also urged to recommend the repeal of the International Crimes Act which domesticated the Rome Statute. The motion was vigorously debated with the members from the opposition vociferously challenging it. Eventually, the opposition MPs left parliament in protest and the motion was passed in their absence. The motion was, nonetheless, passed on $6^{\text {th }}$ of September 2014. This time too, no steps was taken by the government to withdraw from the Rome Statute despite parliamentary approval.

\section{Other Initiatives}

After the confirmation of the charges against Uhuru and Ruto way back in March 2010, the duo used all kinds of methods at their disposal to frustrate the trial, while in public affirming their intention to cooperate with the court. This paradoxical posturing has been the hall mark of Uhuru Kenyatta and William Ruto's approach to the ICC criminal process. On the domestic scene however, there was no pretence about the disdain the two leaders had for the ICC and the international community that supported its work. For example, as the 2013 election drew near, the duo rallied the support of a cabal of leaders from the Kikuyu and Kalenjin communities during "prayer" meetings in which the ICC was roundly condemned. The process of galvanising ethnic support for the withdrawal or termination of the case against Uhuru Kenyatta and William Ruto began before they won the elections in 2013. ${ }^{29}$ Part of the campaign was aimed at creating an image of unpopularity for the ICC's work in Kenya and mobilising a national consensus against government support for the ICC. After the two won elections in 2013, the approach did not change so much, only that now, they were in charge of a government that was obligated to cooperate with the ICC in line with its commitments as a state party to the Rome Statute. Thus, while officially, the duo attended the trials in The Hague, they did everything possible to frustrate the trial. ${ }^{30}$ The paradoxical mix of defiance and reluctant cooperation more or less defined the government's relationship with the ICC since then. At the trial scene, a host of interlocutory applications were being lodged to either terminate the case or simply delay it, ${ }^{31}$ while appearances in court were always a scene of pitiful performance by Kenyan legislators who went to The Hague in doves to voice their displeasure at the ICC proceedings and support the two leaders. ${ }^{32}$ In addition, the

Charles Jalloh, 'Kenya Should Reconsider Proposed Withdrawal from ICC' (EJITALK 18 September 2013) <http://www.ejiltalk.org/kenya-should-reconsider-proposed-withdrawal-from-the-icc/> accessed on 20 October 2016.

Moses Njagih, 'Gema Reveals Plans on ICC' (Standard, 24 March 2012) < > date accessed 11 May 2019. a meeting of the GEMA communities in Limuru in March 2011 resolved Uhuru Kenyatta had the right to contests Kenya's presidency despite the charges he was facing at the ICC. The meeting also condemned ICC as an imperialist agent and urged all Kenyans to distance themselves from it. S Owino, 'Application for a Delayed Trial is Unusual' Saturday Nation (Nairobi 24 March 2012). Sella Oneko and Alfred Kiti, 'Kenya, Uhuru Kenyatta to Attend ICC Hearing at The Hague' (AllAfrica, 9 October 2014) <http://allafrica.com/stories/201410070947.html> accessed 12 July 2016.

31 There were several applications such as seeking to move the trial back to Kenya; excusal of physical presence during trial; challenges on lack of cooperation by the Kenyan government. Felix Olick, 'Will the ICC have a Positive Legacy in Kenya?' (East African Standard, 27 April 2014)

$<$ http://www.standardmedia.co.ke/?articleID=2000110378\&story_title=will-the-icc-have-a-positivelegacy-in-kenya> accessed on 12 July 2016. 
government went on overdrive to mobilise African governments in support of a unified stand against the ICC. And while the duo appeared to cooperate with the court, on the background, witnesses were disappearing while others withdrew their testimony. ${ }^{33}$ The plan was to "eliminate, intimidate, and bribe people who knew too much about the PEV, key individuals who were part of it, and civil society activists who were assisting and sheltering potential witnesses." 34 The purpose was to ensure that "the cases dropped for lack of evidence.... and to destroy the credibility of other witnesses...." 35 The trials dragged on, but with difficulties. In the end, the Prosecutor found herself in a very difficult position. She simply had no evidence against Uhuru Kenyatta and was forced to withdraw the charges. ${ }^{36}$ The same fate befell the cases of William Ruto and Julius Sang.

Despite all what went on and the efforts to withdraw being made, Kenya has not taken concrete steps to withdraw from the Rome Statute. One is therefore forced to question why there has been so much talk and political haranguing on the ICC issue and yet nothing tangible has been done to legally effect the withdrawal. If the true intention of the government was to withdraw from the treaty, why did it not follow the simple procedure set out in article 127 of the Rome Statute? All what is required of states is to give notice to the Secretary-General of the United Nations of their intention to withdraw. The provision does not establish what the notice should contain or how it should be brought to the attention of the Secretary-General of the United Nations. It could be a simple letter conveying the intention to withdraw. Thereafter, the withdrawal takes effect one year after the notice has been served. There is no requirement of any other processes, at least at the level of the United Nations. If the intention of the Kenyan government was to withdraw, why did it not serve its notice? Apparently, this is a step that the government is not willing to take, at least for now. There are geo-political considerations of course and the fact that the government is well aware of dangers of isolating itself from the community of nations. But there is another reason, which informs the basis of the enquiry in this article, which is the fact that no matter how grave political implications of the trials maybe, the ICC framework as a whole is not necessarily incompatible with the transitional justice processes established by the new Constitution (2010) and the legal framework that has evolved from it. And withdrawing from the ICC could mean destroying the pillars of the country's legal system.

In the next section I examine briefly the tenets of this compatibility to illustrate how constitutional imperatives for asserting principles of criminal justice in Kenya are consistent with ICC's work, and to support the argument that domestic legal institutions and the entire infrastructure for justice administration espouse affinity to international standards, which makes them amenable to positive cooperation with the ICC.

\section{Rome Statute's Compatibility with Domestic Law}

Makau Mutua, 'How they tampered with Ocampo witness' (Sunday Nation, 18 March 2012)

<http://www.nation.co.ke/oped/Opinion/How+they+tampered+with+Ocampo+witness+/-

/440808/1368438/-/uc19g2/-/index.html> accessed on 12 July 2016. Catrina Stewart, 'ICC on Trial

Along with Kenya's Elite Amid Claim of Bribery and Intimidation' (The Guardian, 1 October 2013)

<http://www.theguardian.com/world/2013/oct/01/icc-trial-kenya-kenyatta-ruto> accessed on 12

July 2016.

Mueller (n 9) 33.

Mueller (n 9) 34.

Mike Pflanz, 'Uhuru Kenyatta's ICC Prosecution Close to Collapse' (The Telegraph, 8 October 2014)

<http://www.telegraph.co.uk/news/worldnews/africaandindianocean/kenya/11149256/Uhuru-

Kenyattas-ICC-prosecution-close-to-collapse-as-lawyers-demand-acquittal.html > accessed on 12 July 2016. 
The rhetoric of current political leaders has created the false impression that there is nothing in the Rome Statute that is compatible with African values, aspirations and norms. In Kenya, the ICC is vilified as an intrusive organisation that does not respect African leaders and which has nothing to offer to Kenyans by way of improving political governance and the administration of justice. ${ }^{37}$ This claim belies the plethora of reforms in governance and in the judicial sector that have been undertaken since the Moi government was voted out of power in 2002. These reforms have sought to align the domestic institutions of justice administration with international criminal justice standards. In addition, there are several factors which show compatibility of the domestic legal framework with principles of international justice that are often taken for granted, but which, in my view, are important to highlight. To begin with, by ratifying the Rome Statute, Kenya moved closer to adopting international standards in dealing with impunity, while at the same time strengthening its methods of dealing with international crimes. Secondly, with the enactment of a new constitution in 2010 and the establishment of legal and administrative frameworks that support its implementation, a number of legal institutions have emerged that show compatibility with the ICC processes. If anything, these factors show how international law have become entrenched in the Kenyan legal system.

\section{IV.I Constitutional Framework}

The main constitutional imperative which affirms the compatibility of Kenya's legal system with the ICC is the entrenchment of international law in domestic adjudication. ${ }^{38}$ Unlike in the past, domestic courts can now apply international law (treaties and general principles of international law) as part of Kenya's domestic law. ${ }^{39}$ This change has been brought about by article 2 of the Constitution. It provides that, "the general rules of international law shall form part of the law of Kenya" 40 and also that "Any treaty or convention ratified by Kenya shall form part of the law of Kenya under this Constitution". ${ }^{41}$ Although rules of customary international law are not expressly mentioned, one would assume that it was a mere drafting error and that the provision would be interpreted inclusively rather than exclusively. The other provision that is equally instructive is article 132 which lists, as part of the functions of the President, the duty to "ensure that the international obligations of the Republic are fulfilled through the actions of the relevant Cabinet Secretaries". There is enough in these provisions to infer that the international obligations that Kenya has committed to must be taken seriously. Moreover, the constitution has created an opportunity for the use of international and foreign law to resolve domestic disputes. ${ }^{42}$ Indeed, there is ample evidence that international and foreign laws are already influencing domestic litigation in Kenya. ${ }^{43}$ This phenomenon also correlates with intensification of reform movements, the re-emergence

Ochiel J. Dudley, 'ICC's Inherent Weaknesses Hamper its Work' (Daily Nation 22 February 2012).

Nicholas Orago, 'The 2010 Kenyan Constitution and the Hierarchical Place of International Law in Kenyan Domestic System: A Comparative Perspective' (2013) 13(2) AfrHumRtsLJ 414, 439.

See for example Pattni \& Another v Republic (2001) KLR 262 where the courts, although willing to "take account of the emerging consensus of values" embodied in the international human rights instruments, maintained that such laws were only of persuasive value.

Constitution of Kenya 2010, art 2(5).

Constitution of Kenya 2010, art 2(6).

Laurence Juma, 'Nothing but a Mass of Debris: Urban evictions and the right of access to adequate Housing in Kenya' (2012) 12 (2) African Human Rights Law Journal 470.

Ibid 470 . 
of regional and sub-regional frameworks for the administration of justice and the mobility and cross-pollination of rights practice that we now see across Africa. ${ }^{44}$

\section{IV.II Domestication of the ICC Treaty \\ IV.II.I International Crimes Act $2009{ }^{45}$}

The International Crimes Act (ICA) is in many ways a product of the negotiations that brought the post-election violence to an end and established the coalition government of Kibaki/Raila. Within the caucus negotiating on behalf of the main political parties, which had personalities such as James Orengo, who had themselves been victims of brutal repression in previous regimes, the question of how to deal with past violations of human rights and crimes committed during the violence was very much alive. Thus, their recommendation that the Commission of Enquiry into the Post-Election Violence (CIPEV) be established to investigate such violations came as a natural response to the situation. The Commission's work and its report published in October 2008, must have paved the way for the alignment of Kenya's justice system with international standards. Although parliament later reject the Commission's recommendation supporting the establishment of a local tribunal to deal with these crimes, it opted instead to domesticate the Rome Statute by enacting the International Crimes Act. This was done barely two months after the CIPEV report was published, in December 2008. Ironically, the Act was a product of mixed political calculations aimed at defeating justice rather than a genuine endeavor to improve Kenya's justice system and respond to past violations and crimes.

Despite the circumstances of its birth, the Act fits into the scheme of cooperation with State Parties envisaged by the Rome Statute. Article 88 of the Rome Statute requires state parties to establish procedures under national law that enable them to cooperate with the ICC. Kenya fulfilled this obligation by enacting the ICA. The Act proclaims that its purpose is, "to make provision for the punishment of certain international crimes, namely genocide, crimes against humanity and war crimes, and to enable Kenya to co-operate with the International Criminal Court established by the Rome Statute in the performance of its functions." 46 As far as creating the necessary nexus between international law and domestic law, certain provisions of the Act have been overtaken by the Constitution. For example, article 3 of the ICA which provides that the Act is binding on the Kenyan government, and article 4 which states that the Rome Statute has the force of law in Kenya. These two provisions are logical when viewed in the context of the dualist system in Kenya at the time the ICA came into force in 2009. Before the enactment of the Kenyan Constitution of 2010, treaties ratified by Kenya were not automatically incorporated into the laws of Kenya and were considered secondary to municipal law whenever conflict between the two legal regimes arose. ${ }^{47}$ However, by virtue of article 2 of the Constitution discussed above, all treaties and general principles of international law have become part of domestic law.

\section{IV.II.I.I Crimes under the Act}

Tijanyana Maluwa, 'The incorporation of international law and its interpretational role in municipal legal systems in Africa: An exploratory survey' (1998) 23 South African Yearbook on International Law 45 .

'International Crimes Act' [ICA] (2008) No 16 Kenya Law Reports (ed 2012). Ibid, Preamble.

Antonita Okuta, 'National Legislation for Prosecution of International Crimes in Kenya' (2009) 7 JICJ 1063. Discussing the dualist position of Kenya before the enactment of the Kenyan Constitution 2010. 
The ICA refers to the Rome Statute definition of international crimes hence it does not provide an independent definition of crimes that fall under its jurisdiction. It follows, therefore, that article 6 of the ICA provides that the crime of genocide has the meaning ascribed to it under article 6 of the Rome Statute, while war crimes have the meaning ascribed to it under article 8 of the Rome Statute. However, the scope of crimes against humanity in the ICA goes beyond that of the Rome Statute to include definitions provided by conventional international law and customary international law that are not included in the Rome Statute. ${ }^{48}$ Further, ICA incorporates the general principles of criminal law provided for under Part 3 of the Rome Statute such as ne bis in idem, nullum crimen sine lege, individual criminal responsibility, exclusion of jurisdiction over persons under 18, command responsibility, as well as exclusion of statutes of limitation and mental element requirement. ${ }^{49}$ The principles of criminal law and the defenses available under Kenyan law are also applicable according to the act. However, it is noteworthy here that the act also provides that should there be inconsistency between the principles under the Rome Statute and those under Kenyan law, the Rome Statute principles are deemed to take precedence over those under Kenyan law. This is an outstanding provision in view of the dualist system in Kenya at the time of the enactment of the Act under which, as alluded to above, Kenyan law took precedence over treaty obligations in case of conflict.

\section{IV.II.I.II Complementarity}

The act is also compatible with the principle of complementarity under the Rome Statute according to which a national court concerned has primary jurisdictional over a matter and the ICC only gains jurisdiction in case of unwillingness or inability of that state to exercise its jurisdiction. ${ }^{50}$ In this regard, the Kenyan High Court is empowered to try the crimes of genocide, war crimes and crimes against humanity if the crime is committed in Kenya, if the offence is committed by a person employed by the Kenyan government in the military or civilian capacity, if the perpetrator is employed by a state engaged in an armed conflict with Kenya, if the victim is a Kenyan citizen or a citizen of a country allied to Kenya during an armed conflict; or if the perpetrator is present in Kenya after the commission of the offence. ${ }^{51}$

\section{IV.II.I.III Cooperative Mandate}

The Act further regulates and provides procedures for Kenya's cooperation with ICC in various ways. The major type of cooperation it provides for, is with regard to the arrest and surrender of persons to the ICC. Following a request by the ICC under article 89 of the Rome Statute, the Act empowers the High Court of Kenya to issue a warrant of arrest against a person for whom an ICC warrant of arrest has been issued or who has been convicted by the ICC. The High Court of Kenya has already exercised this power, once in 2011, by issuing an arrest warrant against Bashir, the Sudanese president. ${ }^{52}$ However, the duty to arrest and surrender persons to the ICC is not absolute and therefore the Kenyan Minister concerned, may under certain circumstances deny or postpone the execution of an arrest and surrender request. ${ }^{53}$

ICA (n 45) Article 6 (4).

ICA (n 45) Article 7.

See the Admissibility criteria of the ICC under article 17 of the Rome Statute. See Rome Statute of the International Criminal Court (adopted in 17 July 1998, entered into force 1 July 2002) 2187 UNTS 90

ICA (n 45) Article 8.

Kenya Section of The International Commission of Jurists v Attorney General \& another [2011] eKLR.

ICA (n 45) Articles 51-60. 
Other types of cooperation provided for in the ICA match those required of a state party under article 93 of the Rome Statute. These include assistance in locating or identifying persons or things and this may only occur if the AG is satisfied that the person or thing is related to proceedings at the ICC and is located in Kenya. ${ }^{54}$ The ICA also provides for assistance by way of production of documents, protection of witnesses, questioning persons, service of documents, identifying, freezing or seizing property associated with international crimes, enforcement of penalties, as well as assisting the ICC in gathering evidence. ${ }^{55}$ The obligation to assist in gathering evidence was tested when the Office of the Prosecutor (OTP) filed an application to the Court to compel the Kenyan government to avail the financial statements of President Kenyatta. ${ }^{56}$ However, the government argued that the request was in contravention of the Rome Statute, the ICA and the Kenyan Constitution and urged that the application be dismissed. ${ }^{57}$ The Trial Chamber held that the government had failed to cooperate with the Court in this regard and that their action "not only compromised the prosecution's ability to thoroughly investigate the charges but ultimately impinged on the Courts ability to fulfil its mandate." 58

The obligations Kenya owes to the ICC are not one sided as the Act also provides, in accordance with article 93 of the Rome Statute, for instances where the government of Kenya could seek assistance from the ICC. The assistance may be in relation to investigation or prosecution of crimes that fall under the jurisdiction of the ICC or crimes that are punishable under the laws of Kenya by a minimum penalty of 5 years imprisonment. ${ }^{59}$ These requests may relate to any form of assistance which the ICC may lawfully give including transmission of documents or other forms of evidence obtained during the ICC investigation and trial as well as questioning of persons in the custody of the ICC.

\section{IV.II.II Judicial Intervention: Kenyan Section of the International Commission of Jurists (KICJ) v Attorney General and Minister of State for Provincial Administration and Internal Security ${ }^{60}$}

After the Kenyan government had invited and hosted Bashir during the promulgation ceremony of the new constitution in August 2010, there was a simmering discontent among opposition politicians and a great uproar from civil society groups. The visit was seen as having tarnished the image of the country internationally. ${ }^{61}$ Within the political circles, the coalition government seemed divided. Prime Minister Raila Odinga revealed that he had not been consulted about Bashir's visit and placed the blame squarely on President Kibaki's door. The Prime Minister's position undoubtedly energized the civil

ICA (n 45) Article 76.

ICA (n 45) Part V.

Prosecutor v Uhuru Muigai Kenyatta (Decision) ICC-01/09-02/11 (December 3, 2014).

Ibid. Isaiah Lucheli, 'AG: Kenya won't disclose Uhuru's assets to ICC' (Standard Digital News, 24

December

2013) <http://www.standardmedia.co.ke/?articleID=2000100750\&story_title=The\%20Hague $\% 20$ Tri al:\%20AG:\%20Kenya\%20won> accessed 10 October 2016.

Prosecutorv Uhuru Muigai Kenyatta (n 56) para 79.

ICA (n 45) Article 168.

Kenya Section of The International Commission of Jurists $v$ Attorney General \& another (n 52).

Xan Rice, 'Omar al-Bashir tarnishes Kenya's landmark day' (The Guardian, 27 August 2010)

<http://www.theguardian.com/world/2010/aug/27/omar-al-bashir-war-crimes-kenya>accessed 10 July 2016. 
society who now called on the government to honour its pledge of stamping out impunity. The government on its part remained adamant that it was merely responding to the need to promote good neighbourliness and bolster peace in the region. ${ }^{62}$ However, this did not ease tension. So, when President Kibaki announced, during the $65^{\text {th }}$ Session of the United Nations General Assembly held in New York, that he would convene an InterGovernmental Authority Development (IGAD) summit to discuss, among other things, the forthcoming referendum for self-determination of South Sudan, speculation was rife as to whether Bashir would be invited to visit Kenya again. Civil society groups began to agitate for total ban or arrest of Bashir should he visit the country. The ICC also joined the fray. Its Pre-Trial Chamber wrote to Kenya seeking to be furnished with reasons why Kenya did not arrest and surrender Bashir despite two warrants of arrest, ${ }^{63}$ and why it had failed to honour the two cooperation requests the Court had sent to states parties.

In his decision the judge affirmed that the Rome Statute was part of the laws of Kenya and cited article 2 (5) and (6) of the Kenyan Constitution both of which incorporate customary international law and treaties ratified by Kenya into the laws of Kenya. The judge also pointed out that the domestication of the Rome Statute by virtue of the ICA fortified the inclusion of the provisions of the Rome Statute into the Kenyan municipal law. Of particular concern to the court was article 4 of the ICA which provides inter alia that the provisions of the Rome Statute shall be enforceable in Kenya in relation to "the making of requests by the ICC to Kenya for assistance and the method of dealing with those requests". The Judge then waded into the principle of universal jurisdiction. On the strength of a number of foreign cases, such as Pinochet, relating to universal jurisdiction, he found that the duty to prosecute certain crimes within the Rome Statute was peremptory in nature and therefore could not be derogated from. In his view, the duty to prosecute international crimes under the Rome Statute had attained the status of jus cogens and customary international law and was therefore binding on all states whether they were parties to the Statute or not. On the strength of this argument, the judge concluded that the court had jurisdiction over the matter and could compel the government to either extradite or prosecute Bashir as required under the Rome statute. ${ }^{64}$

Although the respondents argued that articles 29, 32 and 33 of the ICA indeed provided that a request for a warrant of arrest should be made by a representative of the state and not private persons, the court held that the applicant had locus standi in the matter on the basis of public interest. In order to arrive at this conclusion, the court referred to the public interest decisions from various common law jurisdictions including the United Kingdom, Australia, and Canada. ${ }^{65}$ The court then proceeded to issue a warrant of arrest against the Sudanese president and stated that any legal person, including the applicant, with the mandate and capacity to enforce the arrest warrant was at liberty to do so. The court, however, stated that in case of Bashir's visit, should the applicant lack the capacity to enforce the warrant, it (the applicant) would have the option to apply to the High Court

'Kenya defends inviting Al-Bashir despite ICC warrants' (Mail \& Guardian 27 August 2010) <> accessed 10 July 2016.The then Minister for Foreign Affairs, Moses Wetangula, issued an official statement confirming the government's position. "Kenya defends inviting Al-Bashir despite ICC warrants" Mail \& Guardian 27 August 2010, <http://mg.co.za/article/2010-08-27-kenya-defendsinviting-albashir-despite-icc-warrants $>$ (accessed 10 July 2016). Prosecutor v. Omar Hassan Ahmad Al Bashir (Decision) ICC-02/05-01/09 (4 March 2009) and Prosecutor v. Omar Hassan Ahmad Al Bashir (Decision) ICC-02/05-01/09-95 (12 July 2010). the Republic of Sudan' (2012) 12 African Human Rights Law Journal 623, 631. 
for an order of mandamus ordering the minister to enforce the warrant of arrest against Bashir. ${ }^{66}$ Whether or not the government will have the courage to effect the warrant should Bashir step on Kenyan soil, remains to be seen.

\section{Prospects for the Future}

The picture which emerges from the foregoing discussions is that international standards of justice are more likely to be enforced by domestic institutions in Kenya than has probably been acknowledged. Indeed, the normative architecture that has been put in place, especially after the promulgation of the 2010 Constitution, together with systems of governance that have emerged from it, are undeniably aligned to principles of international criminal justice. Thus, it may be rightfully concluded that the domestic institutions may constitute a level of hindrance to political machinations aimed at weakening the ICC treaty. But even though this may be the case, there is no question that apart from the Bashir case, the Kenyan cases at the ICC have had perhaps the greatest impact on the courts relationship with African states. ${ }^{67}$ And even now that the cases against Uhuru Kenyatta and Willim Ruto have all been terminated, their effects are still reverberating all through the continent and within AU circles. Some analysts have suggested that the Kenyan cases have undermined the future of ICC involvement in Africa ${ }^{68}$ Accordingly, the role and performance of the ICC "might well be thwarted as member countries and individuals respond to changing political incentives that differ from those of the court and penalize cooperation with it". ${ }^{69}$ After all Kenya was very successful in mobilising AU member states to support their efforts to defeat the ICC criminal process against its leaders. Early in 2011, the AU accepted to back Kenya in its efforts to terminate the cases against its leaders and has since then been consistent in challenging the ICC involvement in Kenya. The AU then made several attempts to have the cases terminated including seeking the deferral under article 16 of the Rome Statute. At some instance it even made a ridiculous representation to the ICC asking the court to refer the cases to Kenya for trial! $!^{70}$ The AU was also able to use its numerical strength to secure concessions at the ICC Assembly of State Parties (ASP) meetings. One notable example is the special dispensation excusing Heads of States from attending their trial which is contained in 134 quarter adopted by the ASP at the $12^{\text {th }}$ Plenary Meeting held in November $2013 .{ }^{71}$ In addition, the efforts have been made to galvanise support of regional bodies as well. For example, in 2012 Kenya persuaded the East African Legislative Assembly to pass a

Ibid, para 24.

Leila Sadat and B Cohen, 'Impunity through Immunity: The Kenyan Situation and the International

Criminal Court' (Legal Studies Research Paper, Washington University in St Louis School of Law December 2015). They are arguing that the Kenyan cases may present a major challenge to the ICC's legitimacy and effectiveness.

Mueller (n 9) 26. O Maunganidze, 'Does the ICC Case Against Kenya's Leaders undermine International Peace and Security' (ISS 13 November 2013)

$<$ https://www.issafrica.org/acpst/news/does-the-icc-case-against-kenyas-leaders-undermineinternational-peace-and-security $>$ accessed 20 July 2016. Abdullahi Halake, 'Does ICC have an African Problem' (Aljazeera 7 February 2014<http://america.aljazeera.com/opinions/2014/2/kenyatrials-keytoiccafricarelations.html) > accessed 20 July 2016.

Mueller (n 9) 26.

Decision on Africa's relationship with the International Criminal Court (ICC), (October 2013)

Ext/Assembly/AU/Dec 1.

ICC Resolution ICC-ASP/12/Res 7, Amendments to the Rules of Procedure and Evidence Resolution (27 November 2013) ICC-ASP/12/20. Sadat and Cohen (n 67) arguing that the rule is incompatible with Articles 63(1) and 27(1) of the Rome Statute of the International Criminal Court. 

resolution that the ICC cases against Kenyan nationals be transferred to the East African Court of Justice. ${ }^{72}$

Kenya's campaign against the court went beyond the African continent. For example, at the $14^{\text {th }}$ Session of the Assembly of State Parties (ASP) meeting in November 2015, Kenya had mobilised all the 33 African countries to support its demands that Rule 68 which allows for the use of recanted evidence be suspended and that a special panel be constituted to investigate the allegations of misconduct by the OTP. ${ }^{73}$ Although Kenya made such a spirited attempt to convince other members that the use of recanted evidence in the Willian Ruto case went against the spirit and assurances by the $12^{\text {th }}$ Session of the ASP held in 2013 that the rule would not be used retrospectively, its position lacked credibility. The OTP's response was perhaps much more telling of Kenya's insincerity in the matter and its purpose to thwart the trial and damage the ICC. In its response, the OTP informed members that the issues that Kenya was raising were the same as those that William Ruto's lawyers raised at the trial and the court's decision was still spending on the matter. As it transpired, the majority of members, mostly outside the African continent (except Mali and Cote d'Ivoire), opposed the demands. ${ }^{74}$ Interestingly most African states neither came out to support Kenya nor opposed its demands. In the end Kenya was only able to get a marginal concession in the form of a restatement in the report of the proceedings that the rule would not be applied retrospectively. ${ }^{75}$

What should be concerning, is the damage Kenya's campaigns against the Court may have inflicted on the international criminal justice system as a whole. That is why the international community should be concerned about how the ICC conducts itself going forward. As suggested, perhaps a more collaborative approach to ending impunity that recognises the importance of the ICC but also strengthens domestic systems is the way to go. Secondly, the Kenyan cases have demonstrated the need to elaborate the issue of heads of state immunity so that it is not used to shield impunity. Whereas too many commentators agree that there is little ambiguity as far as criminal liability is concerned, the controversy created by article 98 and 27 of the Rome Statute has lingering effects and provides some window for contesting responsibility when heads of states are indicted by the Court. The concession by ASP in Rule 134 quarter which excuses heads of states from being present at their trials further exacerbates this uncertainty. The AU has been keen to capitalise on this fact and has requested for what it calls, "comparative analysis of the practical application of Article 27 and 98 of the Rome statute" so as to give due consideration to regional (read African) interests. ${ }^{76}$ Although the AU concerns are not consistent with the goals of justice, there is indeed a case to be made for international elaboration of immunity that may remove any doubts about its applicability in criminal circumstances. In this regard, the UN together with other multilateral bodies could then encourage states to understand that political leaders are not immune from prosecution by international tribunals.

Walter Menya, 'Kenya Fresh Shuttle Diplomacy on ICC Cases' (The Star, 30 April 2012) <> accessed on 11 May 2019. At the East African Community Summit held on 28 $8^{\text {th }}$ April 2012, the leaders recommended that the jurisdiction of the East African Court of Justice be extended to cover war crimes and crimes against humanity.

Mali and Cote d'Ivoire had opposed the listing of Kenya's demands in the agenda of the ASP.

This was no concession at all because Rule 68 already has a similar limitation of retrospective application.

Decision on the Meeting of African State Parties to the Rome Statute of the International Criminal Court (ICC) (3 July 2009) Assembly/AU/Dec 245 (XIII) Rev 1. 


\section{Conclusion}

Undoubtedly, "domestic national tribunals and processes constitute the primary and lasting solution to impunity". ${ }^{77}$ Their role of supporting international enforcement mechanisms is crucial but not fully exploited. Although the intention to frustrate international efforts to eradicate impunity and diminish the work of ICC is clearly evident, there is enough goodwill to defeat these intentions and continue with the work that started at Nuremberg. Moreover, there are indicators that completely dismantling the international justice mechanism will not be easy. Even in Kenya where there is a clear intention to do so from the ruling elite, the process of dismantling the institutions that support international criminal processes, is yet to begin. Despite the parliament's support for withdrawal from the ICC, it is not clear when the Kenyan government will begin to actualise this process. I have argued that even in the case of Kenya, there is still hope for creating a better relationship between the government and ICC as the former still enjoys grass-root support among the peoples of the continent and there is latent support within legal institutions. But the ICC as well as the international community must play their part by seizing opportunities to demonstrate that the Court is not targeting Africans or serving interests that are anti-African. I have suggested that the ICC needs to devise creative ways within its mandate of dealing with African situations that do not necessarily antagonise the continent but still gets the job done, as well as actively using its process to promote the goals of peace and reconciliation in the continent, as mandated by article 53 of the Statute in collaboration with like-minded domestic institutions. 